\title{
So that the evaluation of research is a source of progress
}

While the frenzy of assessment seems to have seized the research systems, it would be worth seeing whether such a development has any negative consequences for knowledge production and for innovation. In particular, faced with such a situation, is there not a risk that researchers prefer the safest way to be properly assessed at the expense of more innovative but riskier ways, often more difficult to evaluate? Such a self-protective tendency can only encourage business as usual instead of engaging in novel ways to tackle new problems.

In the innovation process, it is well known that matters considered as minor today, and therefore depreciated and poorly assessed, may tomorrow become very relevant. It is probably the case for "underutilized fruits" or "minor fruits" that could provide great opportunities for the future in terms of nutrition, income generation and environmental services. How to encourage research on these fruits if they do not meet today's criteria of the current academic assessment systems and if there is a risk for researchers engaging with it with the fear of being wrongly evaluated?

While the GCARD recognizes that research must be better embedded in development and that interaction with the private sector is becoming a key element of efficiency, is there not a risk for a researcher to endorse such a recommendation while his scientific evaluation will be mostly based on his publications in international peer-reviewed journals with impact factor?
To address fast-emerging issues related to climate change, food safety or economic crises, there is, more than ever, a need for flexibility in research and innovation schemes. Is there not a risk for a researcher to adopt this required flexibility rather than stay inside the rails of comfortable academic programs that will allow him to be better evaluated?

Similarly, it is increasingly accepted that multidisciplinary and multisectoral approaches are essential to effectively address the complex problems that affect our world. It is feared that the current assessment systems do not support such approaches as being too embedded within each discipline and sector. It is time to look at how to change behaviors to cope better with the current reality without penalizing researchers who wish to commit today on the risky but innovative research actions, which are the only ones that can open up the paths of innovation and progress in the future. Beyond the single impact factor for journals, the Shanghai ranking for universities or the " $\mathrm{h}$ index" for researchers, it is urgent to look for more realistic and innovative criteria in order to fairly reflect the complexity of innovation.

For its part the journal Fruits intends to engage in this path of progress by ensuring that the subjects off the beaten track are preparing tomorrow's answers to major challenges looming on the horizon, and that the authors involved can get the most out of them.

Dr. Jacky Ganry Scientific Director of Fruits 


\section{Pour que l'évaluation de la recherche soit source de progrès}

Alors que la frénésie de l'évaluation semble avoir saisi les systèmes de recherche, il serait intéressant de voir si une telle évolution n'a pas de conséquences négatives pour la production de connaissances et l'innovation. En particulier, face à cette situation, n'y at-il pas un risque que les chercheurs privilégient les voies les plus sûres pour être correctement évalués, au détriment des voies plus novatrices, mais plus risquées, et souvent plus difficiles à évaluer ? Une telle tendance à s'auto-protéger ne peut qu'encourager les actions routinières au lieu de s'engager sur de nouvelles pistes pour aborder de nouveaux problèmes.

Dans le processus d'innovation, il est bien connu que des sujets aujourd'hui considérés comme mineurs, et donc dépréciés et mal évalués, peuvent demain devenir très pertinents. C'est probablement le cas pour les "fruits sous-utilisés " ou " fruits mineurs " qui pourraient offrir de grandes opportunités pour l'avenir en termes de nutrition, de création de revenus et de services environnementaux. Comment encourager la recherche sur ces fruits si, aujourd'hui, ils ne correspondent pas aux critères des systèmes actuels d'évaluation académique et s'il y a un risque pour les chercheurs de s'y engager avec l'angoisse d'être mal évalués ?

Alors que la GCARD reconnaît que la recherche doit être mieux intégrée dans le développement et que l'interaction avec le secteur privé devient un élément clé de l'efficacité, n'y a-t-il pas là aussi un risque pour un chercheur de suivre une telle recommandation alors que son évaluation scientifique sera principalement basée sur ses publications dans des revues internationales avec comité de lecture et facteur d'impact?

Pour faire face rapidement aux problèmes émergents liés au changement climatique, à la sécurité sani- taire ou aux crises économiques, il y a, plus que jamais, un besoin de flexibilité dans les systèmes de recherche et d'innovation. N'y a-t-il pas là un risque pour un chercheur d'adopter une telle flexibilité nécessaire plutôt que de rester à l'intérieur des rails confortables de programmes académiques qui lui permettront d'être mieux évalué ?

De même il est de plus en plus admis que la pluridisciplinarité et la multisectorialité sont des conditions essentielles pour aborder efficacement les problèmes complexes qui concernent notre monde. Il est à craindre que les systèmes d'évaluation actuels ne favorisent pas de telles approches car encore trop ancrés à l'intérieur de chaque discipline et de chaque secteur. Il est temps de regarder comment changer les comportements pour mieux faire face à la réalité actuelle sans pour autant pénaliser les chercheurs qui souhaiteraient s'engager aujourd'hui dans des actions de recherche innovantes mais risquées, qui sont les seules à pouvoir ouvrir les voies de l'innovation et du progrès de demain. Au-delà du simple facteur d'impact des revues, du classement de Shanghai des universités ou du "facteur h " pour les chercheurs, il est urgent de chercher des critères plus réalistes et innovants, afin de refléter équitablement la complexité de l'innovation.

Pour sa part la revue Fruits entend s'engager dans cette voie de progrès en faisant en sorte que les sujets abordés sortent des sentiers battus pour préparer les réponses de demain aux grands enjeux qui se profilent à l'horizon, et que les auteurs impliqués puissent en tirer le meilleur bénéfice.

Dr. Jacky Ganry Directeur scientifique de Fruits 